\title{
POSSIBILITIES FOR THE DISCHARGE OF MANAGERS IN JOINT STOCK COMPANIES-DIFFERENCES BETWEEN THE ONE AND TWO-TIER MANAGEMENT SYSTEMS AND THE LIMITED LIABILITY COMPANIES
}

\author{
Dr. Borut Bratina*
}

\begin{abstract}
In this article, the author analyzes and compares different possibilities of discharging management board members (i.e. members and the president of the management board) in a joint stock company, in one- and two-tier governance systems, and the discharge of directors in a limited liability company. The author points out the distinction between the status of a management board member appointed by the supervisory board and the status of the executive director appointed by the board of directors. This distinction is especially relevant in case of an early ending of the mandate, since the management board is a body of the company, whereas the executive director is a person authorized (only) by the board of directors. According to the second paragraph of Article 268 of the Slovenian Companies Act (hereinafter referred to as ZGD-1), a discharge of the management board member in the two-tier system is allowed only in cases defined by law, whereas the board of directors can always discharge the executive director according to Article 290 ZGD-1. A similar regulation applies also to the directors of limited liability companies, where shareholders can always discharge the director according to Article 515 ZGD-1. Case law in connection to disputes in these matters has changed through time in Slovenia, which is illustrated in detail by the author. The newest case law is being compared to relevant foreign (especially German) case law.
\end{abstract}

INTRODUCTION

I. Discharge of A MANAGER (A PRESIDENT OR A MEMBER OF THE MANAGEMENT BOARD) 680

II. LEGITIMATE REASONS FOR THE DISCHARGE ……..................................68

III. LEGAL POSITION OF EXECUTIVE DIRECTORS...........................................689

IV. Discharge OF A MANAGER (DIRECTOR) IN A LIMITED LIABILITY

COMPANY

CONCLUSION.

\footnotetext{
* Doctor of Laws, Associate Professor at the Faculty of Economics and Business at the University of Maribor. Research fields: Business Law, Corporate and Finance Law, Corporate Governance.
} 


\section{INTRODUCTION}

In Slovenian corporate practice, there is a large conceptual confusion as regards the possibilities for the discharge of companies' managers. Company members are most often called "owners" and are consequently attributed the rights that are otherwise granted (only) to the company owners. As a result, we often deem that, in terms of appointment and discharge of managers who run and represent the companies, "the owners can freely choose who will run their company and can also replace or discharge that person at any time". Legislation is closest to such position as regards limited liability companies, where the company members are given vast corporate (membership) rights, with the third paragraph of Article 515 ZGD-1 expressly stipulating that the general meeting may discharge the manager at any time, notwithstanding whether the manager has been appointed for a fixed period or indefinite period of time. Yet, the memorandum of association may define that the general meeting is allowed to discharge the manager only for the pre-defined reasons. For the claims related to the appointment contract, the general rules of obligation law are used. Discharge of joint stock companies' executive directors in one-tier management system is also simplified. In those cases, the right to discharge an executive director is not given to the shareholders (i.e. the owners), but to the board of directors which can, in accordance with the eighth paragraph of Article 290 ZGD-1, discharge an executive director at any time. Again, for the executive directors' claims related to the contract on the execution of their duties, the general rules of obligation law are applicable. In practice, this means that joint stock companies' executive directors and managers of limited liability companies can in fact be discharged at any time and without stating the reasons for the discharge. Possible severance pays or damages for the early termination of the contract of appointment are governed by the rules of obligation law. To simplify, the "owner" can discharge "his manager" at any time without stating any reasons for the discharge, as long as he pays him the severance pay or damages. In the two-tier management system, the regime is much different, as will be described in the text below.

Appointment and discharge of the president and individual members of the management board is the legally defined power of the supervisory board ${ }^{1}$ and, simultaneously, one of its most important duties. Professional selection of the appropriate president and members of the management board facilitates the supervision of how the company's business is run and, according to Article 281 ZGD-1, amounts to the most essential competence

\footnotetext{
${ }^{1}$ Article 268 ZGD-1.
} 
and obligation of the supervisory board.

Appointment of the management board presents a corporate legal act executed at the beginning of the mandate, while the discharge presents a corporate legal act indicating the end of the mandate. At the beginning of the mandate, it is important to distinguish the appointment from the conclusion of the (appointment/employment) contract, and, similarly, at the end of the mandate it is necessary to distinguish the discharge from the termination of the contract (and possible termination of the employment relationship) concluded between the president or the member of the management board and the company. Appointment of the president or the individual member of the management board and conclusion of the contract are tightly connected, however, they present two independent legal relations. This also applies to the discharge and termination of the contract concluded with the president or with the member of the management board.

Early discharge of the president or the member of the management board indicates the end of the corporate legal relationship with the company and, generally, causes also the termination of the contract, that is the termination of the contractual legal relationship with the company. In case the president or the member of the management board is in an employment relationship with the company, the situation is even more complicated. In such case, it is crucial whether the employment contract was concluded for a definite or an indefinite period of time. If the president or the member of the management board was employed for a definite period of time, including for the time of mandate duration, the discharge presents a lawful reason for the termination of the employment contract. However, if the employment relationship was set to last for an indefinite period of time, the employment contract can be terminated only under the conditions set by the labor legislation. The latter does not envisage the discharge as a lawful reason for the termination of the employment contract, which means that the procedure for the extraordinary termination needs to be carried out and the fault-based grounds need to be established. The only alternative is termination on the commercial grounds. That is also the case law in Slovenia.

\section{Discharge of A Manager (A President or A Member of the MANAGEMENT BOARD)}

The president and the members of the management board in the twotier management system have an original authority, since the management board is an independent body of the joint stock company, having legally defined powers. In order for the management board to remain independent 
in executing its original authority, ${ }^{2}$ the second paragraph of Article 268 ZGD-1 clearly stipulates when and for what reasons the supervisory board may discharge a particular member or the president of the management board. Since the supervisory board is not the body of the "owners" but an independent body of the company having its own original legal authorities, it is not possible to empower it to discharge the members or the president of the management board on its own discretion. When appointing and discharging the members and the president of the management board, the supervisory board has to follow the rules on diligence and responsibility, enacted in Article 263 ZGD-1. In accordance, when appointing and discharging the members or the president of the management board, the members and the president of the supervisory board must act with the diligence of a conscientious and fair manager. This means that, when discharging a member or the president of the management board, they have to take into account the company's interests and carefully assess whether the discharge is based on the legal reasons listed in the second paragraph of Article 268 ZGD-1. The legality of the supervisory board's decision on the discharge of the members or the president of the management board may be contested in court.

In Slovenian corporate practice, a predominant opinion exists that it is difficult to validly discharge the members or the president of the management board. Such position dominates especially as regards the discussions on the discharge of members and the president of the management board of state-owned companies, where the politics has a strong formal and informal influence. In such cases, the assumption that the shareholders (company members), as the "owners", are supposed to have an unlimited right to appoint and discharge the managers of "their" companies, is abused. Of course, the representatives of the state's shares in the companies do not have the status of the "owners", but, most of all, have the duty to diligently execute their corporate (membership) rights in those companies. In practice, a problem occurs because the (official and unofficial) politics wishes to have an impact on the staff of the state-owned companies, replacing the existing managers with "their" members whenever there is a change of government or governmental coalition. In case of a replacement of inadequate members or presidents of management boards, no problems should occur, since ZGD-1 explicitly allows for the discharge of those members or presidents of management boards that are in serious breach of

\footnotetext{
${ }^{2}$ First paragraph of Article 265 ZGD-1 stipulates that the management board shall direct the business operations of the company independently and at its own liability, while the first paragraph of Article 266 ZGD-1 states that the management board shall act on behalf and represent the company.
} 
their obligations or are incapable of conducting business. However, the issue is that the reason for the replacement is often not of an economic nature and remains unpublished, while other reasons that actually do not exist and do not withstand legal assessment are publicly stated. The solution in such situation is easy as regards private companies, where the "real owners", through the supervisory board, offer the discharged management board members a suitable remuneration and reach with them an agreement on the consensual termination of the contract. Notwithstanding, in companies with a state shareholding, such practice is not common, which is why legally controversial discharges occur and are later solved in court, many times to the company's detriment. ${ }^{3}$ In the past, Slovenian courts rejected the assessment of the validity of supervisory boards' decisions, stating that ZGD-1 does not provide for the judicial protection as regards invalidity of supervisory boards' decisions but allows only for judicial assessment of nullity and contestability of the general meeting resolutions. ${ }^{4}$ In the case III Ips 243/2008, the Supreme Court of the Republic of Slovenia has finally recognized the possibility of exercising invalidity (nullity) of supervisory board's decisions. The court of first instance has rejected the action challenging the supervisory board's decisions, while the appellate court has confirmed the position held by the court of first instance and stated that the claims for the nullity and invalidation of the supervisory board's decisions are unsubstantiated, since the Slovenian legal system does not envisage such sanctions. In a vast explanation, the Supreme Court has later clearly reasoned its position on the use of legal remedies against the decisions of the supervisory board.

First, the Supreme Court has pointed out that, for the assessment of invalidity of supervisory board's decisions, the provisions of ZGD-1 on the nullity and contestability of the general meeting's decisions cannot be used by analogy. Use of those provisions by analogy was rejected by the Supreme Court due to the following reasons: (1) A materially different nature of the relationships that are formed between the shareholders and between the members of the supervisory and management boards of the joint stock company; (2) Generally, a substantially different contents and purpose of the decisions of the two joint stock company's bodies in terms of public confidence and the confidence of current and future investors in the

\footnotetext{
${ }^{3}$ Port of Koper is the latest such case, where the decision on the discharge of the president of the management board was declared null and void by the Koper District Court, due to the contradiction with Article 268 ZGD-1.

${ }^{4}$ For more and more in-depth see Bratina, Velikikomentar ZGD-1 (Great Commentary of ZGD-1), 2nd book, at $133-158$.
} 
joint stock company's assets. ZGD-1 has established a precise legal order for the assessment of invalidity of general meeting decisions, thus excluding the use of the rules on the sanctions for the invalidity of contracts, included in the Code of Obligations, by analogy. Since ZGD-1 failed to introduce such arrangement also as regards the decisions of other joint stock company's bodies, it is the Supreme Court's position that legal vacuum exists and calls for the reflection on possible analogous (and, in accordance with Article 14 of the Code of Obligations, reasonable) use of sanctions for invalid legal transactions as adopted in the obligations law. ${ }^{5}$ Based on such reasoning, the Supreme Court has clearly stated that, in case the supervisory board's decision has a constitutive effect, analogous (and, in accordance with Article 14 of the Code of Obligations, reasonable) use of the provisions of Code of Obligations on the invalidity of contracts should be taken into account. In the first place, this is necessary to assure legal certainty. It is precisely legal certainty that, according to the Supreme Court, on the other hand requires an afterthought on the similarity between the situations foreseen in the Code of Obligations and the circumstances of each particular case. Only if the circumstances of the case are materially similar to the situation governed by law, analogous (and, in accordance with Article 14 of the Code of Obligations, reasonable) use of sanctions for the invalidity of contracts, laid down in the Code of Obligations, is allowed when assessing allegedly "invalid" supervisory board's decisions having a constitutive effect. With this Supreme Court's opinion, the incoherent case law in the field of assessment of invalidity of supervisory board's decisions is finally overcome. The Supreme Court's decision can be fully agreed with.

A supervisory board's decision is a corporate legal transaction and can, as such, be null and void. ${ }^{6}$ The view taken by the majority is that a supervisory board's decision can be null and void if, during the adoption procedure or in terms of its contents, law or memorandum of association were materially violated. ${ }^{7}$

\footnotetext{
${ }^{5}$ The Supreme Court of the Republic of Slovenia has, in case II Ips 65/98, already in the year 1999 stated its position on the possibility of claiming invalidity of supervisory boards' decisions, relying upon the provisions of the Court Register of Legal Entities Act (ZSReg) that foresee court jurisdiction in case of preliminary questions, whereby disputed preliminary questions may include the question on the (in) validity of supervisory board's decisions (cf. Article 33 ZSReg), which can also be subject of the proceedings following the suit for the nullity of the entry into the court register according to Article 41 ZSReg.

${ }^{6}$ See Borut Bratina, Dušan Jovanovič (ed.), Peter Podgorelec, and Andreja Primec. Pravodružb in gospodarskopogodbenopravo (Companies Law and Commercial Contract Law). Maribor, De Vesta, 2011, at 777-779.

${ }^{7}$ Hüffer, the author also cites German case law.
} 


\section{LEGITIMATE REASONS FOR THE DISCHARGE}

Throughout the world, various possibilities for the discharge of managers exist; Discharge without reasonable grounds, discharge for reasonable grounds, discharge for fault-based grounds and discharge for non-fault-based grounds. Each type of discharge has its characteristics and specifics. The least legal certainty is a manager offered in case of a discharge without any stated reasons (this is the case when the general meeting discharges the members of the supervisory board), which is, according to ZGD-1, not possible in joint stock companies, however, it can still happen in limited liability companies. After the adoption of the amendment ZGD-1F, in Slovenia, only the discharge for reasonable grounds is allowed. Yet, it needs to be defined what in practice presents reasonable grounds for the discharge. The difference between the fault-based and the non-fault-based discharge lies in the fact that, as regards the fault-based discharge, the manager is responsible for the existence of the reasonable grounds for the discharge. Possible severance pay depends on the responsibility of the manager for the existence of the reasonable grounds for the discharge. Only in case the manager is not responsible for the discharge he is entitled to a severance pay. ${ }^{8}$ In case of judicial proceedings, the court needs to determine the existence of the discharge reason, which will be further demonstrated below.

After the adoption of the amendment ZGD-1F, discharge for no reasonable grounds is not possible anymore. The reasons for the discharge are now defined in the second paragraph of Article 268 ZGD-1 which states that individual members or the president of the management board may be discharged by the supervisory board:

- If they are in serious breach of their obligations;

- If they are incapable of conducting business;

- If the general meeting passes a vote of no confidence in them, except where the vote of no confidence is passed for clearly unsubstantiated reasons $;^{9}$

\footnotetext{
${ }^{8}$ In accordance with the new European practice, shareholders should have the possibility to adopt the policy on the revenues of management board members and executive directors; consequently, it was introduced into ZGD-1 (sixth and seventh paragraph of Article 294) that the general meeting may define a remuneration policy for members of the management or supervisory bodies. An additional limitation exists, namely, severance pay may be paid only in the case of early termination of the contract. Severance pay shall not be paid if the member of the management board or the executive director has been discharged for the reasons specified in the first, second and third indents of paragraph 2 of Article 268 ZGD-1, or if the management board member or executive director terminates the contract.

${ }^{9}$ Following the no-confidence vote, in case there no reasonable grounds, exposes the supervisory board to possible damages liability. See Borut Bratina, et. al., Op. Cit., at 714.
} 
- For other economic and business reasons (significant changes in the shareholder structure, reorganization, etc.).

According to the amended regime (amendment ZGD-1F was adopted in the year 2001), the supervisory board is entitled to discharge individual members or the president of the management board, however, it needs to comply with the statutory provisions that define the reasons for a legitimate discharge. In accordance with its corporate duties, the supervisory board must throughout the management board's mandate monitor the management board's work also in terms of existence of reasons for an early discharge of its members. In case such reasons exist and the statutory board fails to replace the member or the president of the management board, it can be held liable for the damage caused to the company by such omission. Vice versa, the same can be said if the members or the president of the management board are discharged without reasonable grounds.

The aim of the amendment ZGD-1F was to exclude the discharge from the supervisory board's discretion and to require the supervisory board to state and substantiate the reasons for the discharge. In that way, Slovenian legislation was approximated to the German ${ }^{10}$ and Austrian ${ }^{11}$ corporate laws, which allow the discharge only in case required reasons exist, otherwise, the discharge is invalid, which is determined by the competent court. In the case III Ips 195/2008, the Supreme Court of the Republic of Slovenia has adopted a position on proving the existence of the reasons for a legitimate discharge. In accordance with the established case law of the Supreme Court of the Republic of Slovenia, it is deemed that the management board was discharged without reasonable grounds if the reasons for the discharge are not described in the supervisory board's decision. ${ }^{12}$ Accordingly, it can also be said that, in case the reasons are stated in the supervisory board's decision, it is deemed that the member of the management board was discharged for reasonable grounds and that the discharged member of the management board must prove in court that the grounds for the discharge do not exist. Pursuant to the established case law of the Supreme Court of the Republic of Slovenia, the supervisory board does not have to explain the reasons for the discharge into such details that would include statements on the discharged management board member's specific acts or omissions of particular legal or contractual obligations. Yet, the Supreme Court of the Republic of Slovenia alerts that the opposite extreme, which would allow only general allegations regarding the reasoning of the discharge, can also

\footnotetext{
${ }^{10}$ Article 84 dAktG.

${ }^{11}$ Article 75 aAktG.

${ }^{12}$ See also the decision of the Supreme Court of the Republic of Slovenia, nr. VIII Ips 103/2004.
} 
not be accepted, since this could overly burden the discharged member of the management board by requiring him to substantiate its entire activity and the business decisions he has adopted. Further, the Supreme Court states the examples that meet the standard of being sufficiently described in the supervisory board's decision and that allow for an objection: Deficiency and inappropriateness of rehabilitation measures, invisibility of the business strategy rehabilitation, unsuitable monitoring of investments; ${ }^{13}$ inability of efficient business conduct due to the collisions between the members of the management board; ${ }^{14}$ poor business results. ${ }^{15}$

Proving the non-existence of reasons indicated in the supervisory board's decision is the subject of litigation related to the severance pay. In such case, concretization of claimant's actions and business decisions that present the basis for the supervisory board's decision is required. It is material that the court's assessment relates only to the reasons that were discussed at the session where the supervisory board's decision was adopted. Accordingly, the company cannot claim in court additional discharge reasons that were not indicated in the original supervisory board's decision.

It is the Slovenian Supreme Court's position that the indication of reasons in the decision on the discharge is only a formal precondition for the further substantive assessment of the (in) validity of the discharge reasons. Such assessment is only possible taking into account the parties' indications on the particular actions and business decisions that were made in accordance with the prescribed duties of the management board and, on the other hand, the indications on the omissions of concrete legal or contractual obligations.

ZGD-1 indicates practically the same reasons for the discharge as the German and Austrian corporate legislation. Yet, it needs to be specifically pointed out that the reasonable grounds for the discharge are not necessarily linked to the guilt of the discharged management board member, ${ }^{16}$ moreover, in accordance with the German legal theory not necessarily even with the breach of his obligations. ${ }^{17}$ Interesting is also the position established in German case law, leaving the decision on which member of the

\footnotetext{
${ }^{13}$ Decision of the Supreme Court of the Republic of Slovenia,nr. VIII Ips 554/207.

${ }^{14}$ Decision of the Supreme Court of the Republic of Slovenia, nr. VIII Ips 264/2007.

${ }^{15}$ Decision of the Supreme Court of the Republic of Slovenia, nr. VIII Ips 47/2001.

${ }^{16}$ Decisions: BGH of July 11, 1955, nr. II230/54; BGH of February 24, 1992, nr. II ZR 79/91; OLG Stuttgart of March 13, 2002, nr. 20 U 59/01.

${ }^{17}$ See Koellner, Kommentar AktG, commentary to Article 84, Rn. 103, where he states that a legitimate reason for the discharge exists also when the management board or the company are restructured in such a way that the management board member no longer corresponds to the new composition of the management board.
} 
management board shall be discharged in case a reason for the discharge exists with more members to the supervisory board. ${ }^{18}$ The question of faultbased reasons is addressed in connection with the damage liability of the discharged management board member or, on the contrary, the company's damage liability if the contract between the company and the member of the management board was terminated at the company's will, without management board member's guilt.

There is a certain nomo-technical difference between the German, Austrian and Slovenian regime of the early discharge. In German and Austrian law, the reasons for the legitimate discharge are listed by example $^{19}$, while ZGD-1 allows the discharge also for other economic and business reasons which have to be indicated and substantiated by the supervisory board in the decision on the discharge. As a general rule, in Germany reasonable grounds for the discharge exist "if it is determined that it is no longer suitable or beneficial for the company that the member or the president of the management board continues to exercise his function".

In accordance with the $\mathrm{dAktG}^{20}$, the discharge is valid as long as its invalidity is not finally determined. There is no similar provision in ZGD-1, however, the same principle applies also in Slovenian corporate legislation. The longest term of office according to ZGD-1 amounts to six years. If legal proceedings are commenced due to the early discharge, the term of office is not prolonged. In practice, this means that, in most cases, the discharge is final, since legal proceedings are very rarely finally concluded before the term of office expires. ${ }^{21}$ The supervisory board can also adopt a new decision on the discharge and offer a new justification, if the court invalidates the previous discharge decision. As a consequence, the possibility for a successful reintegration claim (return to the management board) is very low; ${ }^{22}$ much more important is the decision on possible damages caused by the unfounded discharge. In that regard, the question of adopting an interim decision during the court proceedings initiated after the discharge is very important. German theory rejects a possibility of an interim decision which would suspend the effect of the discharge, since this

\footnotetext{
${ }^{18}$ Decisions: BGH of July 13, 1998, nr. II ZR 131/97; OLG Stuttgart of March 13, 2002, nr. 20 U 59/01; OLG Saarbruecken of July 31, 2006, nr. 8 U 269/03-56.

${ }^{19}$ As established by the uniform legal theory and case law in Germany and Austria, e.g. MeyerLandrut, Großkommentar, at 652; Kastner, Doralt, Nowotny, str. 226.

${ }^{20}$ Second paragraph of Article 84.

${ }^{21}$ H. J. Mertens, Kölnerkommentar, at 174.

${ }^{22}$ Contrary to the German case law, Slovenian courts do not recognize reintegration claims (return of the discharged member to the management board), since such claims are not expressly provided for in ZGD-1.
} 
would present a circumvention of the legal provisions on the effectiveness of the discharge (however, an interim decision is possible in case of a formal mistake). ${ }^{23}$ In Slovenia, this will eventually be independently decided by the court, since ZGD-1, contrary to the dAktG, includes no provisions that would preclude such interim decisions from being adopted.

In the already mentioned decision of the Slovenian Supreme Court ${ }^{24}$, it is stated that the discharged manager (as a member of the management board) is not entitled to the reintegration claim, since this is not expressly foreseen in ZGD-1. Yet, in the text that follows this statement, the court acknowledges the discharged management board member's right to the severance pay and to the restitution of damage in accordance with the general principles of tort law.

We can certainly accept the Supreme Court's position that the most important legal protection given to the discharged manager is his right to the severance pay and to the restitution of damage, not his return to the function contrary to the supervisory board's wishes. Reintegration claim would only give the (unjustifiably) discharged member of the management board a better legal position as regards his claim for the restitution of damage.

Especially in German law, extensive case law on the determination of justifiable causes for the discharge exists. Since the Slovenian legislation is in essence very similar, German case law and legal theory can facilitate the enforcement of relevant provisions of ZGD-1. For this reason, let us list some of the legitimate reasons for the discharge as can be found in the German case law and legal theory: ${ }^{25}$ misuse of company's assets for own benefits, disagreements between the members of the management board that disable joint work ${ }^{26}$, delict behavior, rejection of reporting to the supervisory board or inadequate or misleading reports to the supervisory board $^{27}$, misleading or concealing important matters from other management board members ${ }^{28}$, impairing company's goodwill by executing speculative transactions $^{29}$, abuse of authority and membership in the management board

\footnotetext{
${ }^{23}$ H. J. Mertens, Kölnerkommentar, at 174.

${ }^{24}$ VIII Ips 239/2005.

${ }^{25}$ Hoffmann-Becking, at 140.

${ }^{26}$ Decisions: BGH of October 17, 1983, nr. II ZR 31/83; BGH of February 24, 1992, nr. II ZR 79/91; OLG Duesseldorf of June 30, 1988, nr. 6 U 310/87; OLG Duesseldorf of July 07, 1994, nr. 16 U $104 / 92$.

${ }^{27}$ Decisions: BGH of March 26, 1956, nr. II ZR 57/55; BGH of July 13, 1998, nr. II ZR 131/97; OLG Saarbruecken of July 31, 2006, nr. 8 U 269/03-56; L G Muenchen I of November 11, 2004, nr. 5 HKO 6764/04.

${ }^{28}$ Decisions: BGH of July 13, 1998, nr. II ZR 131/97; OLG Muenchen of July 14, 2005, nr. 6 U $5444 / 04$.

${ }^{29}$ Decision of BGH of January 25, 1956, nr. VI ZR 175/54.
} 
for own benefits, long-lasting illness, lack of necessary knowledge, experience and competence necessary for running the company in specific situations (e.g. rehabilitation) ${ }^{30}$, high indebtedness of the member or the president of the management board ${ }^{31}$, in case of companies subject to special supervision (e.g. banks, insurance companies, etc.), a legitimate reason for the discharge is also the request of the supervisory body for the replacement of particular management board members, while establishment of branches, restructuring of production plants and mergers also present legitimate reasons. Additionally, reasonable grounds for the discharge exist also in case the discharge is requested by the crediting bank that gives the company vital "support" for its existence. ${ }^{32}$

A special reason for the discharge exists also if a no-confidence vote is passed at the general meeting, except where the vote of no confidence is passed for clearly unsubstantiated reasons. For the no-confidence vote to be passed, a special decision needs to be adopted, since, according to the fourth paragraph of Article 294 ZGD-1, if no discharge is granted to the management board or any of its members by the general meeting, this shall not imply no confidence (by issuing a discharge, the general meeting confirms and approve the work of the management or supervisory bodies for the financial year).

Examples of no-confidence votes passed for clearly unsubstantiated reasons are: if the management board refuses to execute an illegal decision adopted by the general meeting; passing a no-confidence vote only to repair the supervisory board's decision indicating questionable discharge reasons; if the no-confidence vote relates to the reason that has previously presented the grounds for a discharge.

As regards these disputes, an arbitration agreement is not possible. ${ }^{33}$

Arbitration could have the jurisdiction only if the dispute related to the management board member's or the president's contract of appointment.

\section{LEGAL Position of EXECUTIVE DireCtors}

In the one-tier management system, the position of executive directors resembles the position of management board members in the two-tier management system. Nevertheless, a significant difference exists since the executive directors are not members of a special management body (i.e. the

\footnotetext{
${ }^{30}$ Decision of OLG Muenchen of October 13, 2005, nr. 13 U 1949/05.

${ }^{31}$ Decision of OLG Hamburg of August 27, 1954, nr. 1 U 395/53.

${ }^{32}$ Decision of OLG Muenchen of October 13, 2005, nr. 23 U 1949/05, in the same case also the decisions of BGH of October 23, 2006 and December 04, 2006, nr. II ZR 298/05.

${ }^{33}$ Also in the German Law, H. J. Mertens, at 269.
} 
management board), but have their competences set by the board of directors at the time of their appointment. Consequently, the mandate of executive directors is not safeguarded as the mandate of management board members and the board of directors may, in accordance with the eighth paragraph of Article 290 ZGD-1, discharge the executive directors at any time (discharge without reasonable grounds). For the executive directors' claims arising from the appointment contract, according to ZGD-1, rules of obligations law apply. In case the executive director is simultaneously also a member of the board of directors, the discharge does not result in the termination of his membership in the board of directors, it affects only his executive director position. For the discharge of all members of the board of directors, the competence is vested in the general meeting.

\section{Discharge OF A MANAGER (DIRECTOR) IN A LIMITED LiABILITY COMPANY}

Contrary to the joint stock companies, where the company management and the competences of management bodies are more or less mandatorily determined, the management of limited liability companies is left to the autonomous regulation within the memorandum of association. ${ }^{34}$ In Article 504, ZGD-1 stipulates that the company members' rights relating to corporate governance and the manner in which those rights are exercised shall be set out in the memorandum of association. However, each limited liability company needs to have at least one manager (director) who manages the company's operations and represent the company at his own responsibility. In the memorandum of association, company members may regulate the manner and merits for the appointment of managers into more details. ${ }^{35}$ Very often, one of the company members is appointed as the manager by the means of a specific provision included in the memorandum of association. The memorandum of association may provide that a manager shall be appointed for an indefinite period of time (which is, as regards joint stock company's management board, not possible) or for a fixed period of time of no less than two years. The same person may be reappointed as the manager. ${ }^{36}$

Taking into account the autonomous regulation of limited liability companies' management, the third paragraph of Article 515 ZGD-1

\footnotetext{
${ }^{34}$ More specifically Zabelin Velikikomentar ZGD-1 (Great Commentary of ZGD-1), 2nd book, at 909 et seq.

${ }^{35}$ Zabel, Op. Cit., at 940.

${ }^{36}$ Second paragraph of Article 515 ZGD-1.
} 
logically states that the general meeting may discharge the manager at any time, notwithstanding whether the manager has been appointed for a fixed period or indefinite period of time. Accordingly, the discharge for no particular reasons is legally allowed. Of course, the memorandum of association may determine that the manager shall only be discharged for the reasons specified therein. This does not prevent the possibility of a discharge without a compelling reason, however, it does have an effect on the manager's claims towards the company in case of such discharge ${ }^{37}$ For the claims related to the contract of appointment, rules of obligations law apply.

Severance pay to be provided to the discharged manager may be contractually defined in advance. Additionally, the manager is entitled to seek compensation for the damage caused with the discharge in case he was discharged without his guilt.

In limited liability companies, upon company members' will, a supervisory board may be established. In such case, the provisions on the supervisory board of a joint stock company shall apply, mutatis mutandis, to the supervisory board, unless otherwise provided by the memorandum of association.

\section{CONCLUSION}

The possibilities and procedures for the discharge of managers depend on the type of the company, management system and the autonomous regime set up in each particular company. We can note that inadequate and unconscientious managers may be discharged in any case, while the discharge without stating the (legitimate) reasons is possible only as regards executive directors and limited liability companies' managers. In joint stock companies with the two-tier management system in place, early termination of the mandate of individual members or the president of the management board without reasonable grounds is possible only in case of a consensual resignation of the member or the president of the management board, whereby a severance pay must be properly defined.

${ }^{37}$ Zabel, Op. Cit., at 944. 